\title{
Pengaruh Likuiditas dan Solvabilitas Terhadap Profitabilitas (Studi Kasus Pada Perusahaan Manufaktur Sub sektor Makanan dan Minuman yang Terdaftar di BEI Periode Tahun 2012-2016)
}

\author{
${ }^{1}$ Thomas Nadeak \\ 2F.Pratiwi \\ 1,2 UniversitasBuana Perjuangan \\ Email: misterichi@yahoo.com
}

\begin{abstract}
Abstrak Penelitian ini bertujuan untuk mengetahui Pengaruh Likuiditas dan Solvabilitas Terhadap Profitabilitas (Studi Kasus pada Perusahaan Makanan dan Minuman yang terdaftar di Bursa Efek Indonesia (BEI) Periode 2012-2016). Penelitian menggunakan metode penelitian kuantitatif. Teknik yang digunakan dalam pengambilan sampel yaitu Nonprobability Purposive Sampling. Nonprobability Purposive Samling yaitu teknik penentuan sampel dengan pertimbangan tertentu. Untuk mengumpulkan data, menggunakan dokumentasi. Teknik analisis yang digunakan dalam penelitian ini adalah analisis regresi linear berganda. Nilai signifikan untuk variabel Current Ratio = 0,001, Debt to Equity Ratio = 0,032 nilai variabel tersebut signifikan < 0,05, sehingga Carrent Ratio dan Debt to Equity Ratio secara parsial berpengaruh terhadap Return On Asset. Nilai R square yang diperoleh sebesar 0,225 menentukkan bahwa Profitabilitas dipengaruhi 22,5\% oleh variabel bebas (Curret Ratio dan Debt to Equity Ratio) dan 77,5\% merupakan pengaruh faktor yang lain yang tidak diteliti dalam penelitian ini.
\end{abstract}

Kata Kunci : Likuiditas, Solvabilitas dan Profitabilitas

\section{Pendahuluan}

Pertumbuhan bisnis makanan dan minuman masih tercatat sebagai pertumbuhan yang tinggi diberbagai belahan dunia. Berbagai tempat bisnis makanan dan minuman menawarkan produknya dalam berbagai banyak bentuk yang bermunculan. Mulai dari yang sederhana hingga yang mewah, dan pada umumnya berlokasi didaerah-daerah yang strategis. Hal yang disebabkan karena makanan dan minuman salah satu kebutuhan pokok yang harus dipenuhi oleh semua orang.

Tingkat Profitabilitas perusahaan yang tinggi menunjukkan posisi pemilik perusahaan serta daya saing perusahaan. Rasio likuiditas menggambarkan kemampuan perusahaan dalam memenuhi kewajiban jangka pendeknya yang diproksikan dengan current ratio. Current ratio digunakan untuk menunjukkan 


\section{Jurnal Buana Akuntansi}

ada tidaknya mengenai likuiditas perusahaan. Current ratio yang terlalu rendah maupun terlalu tinggi akan menjadi masalah bagi perusahaan.

Sementara rasio solvabilitas menunjukkan seberapa banyak perusahaan didanai melalui utang. Proksi yang digunakan dalam mencerminkan rasio solvabilitas adalah debt to equty ratio (DER) karena DER diharapkan akan mampu mengukur seberapa jauh modal pemilik dalam menutupi utang-utang perusahaan.

Objek perusahaan yang digunakan dalam penelitian ini adalah perusahaan yang masuk dalam Bursa Efek Indonesia (BEI) yang tergolong dalam sektor industri barang konsumsi.

\section{Rumusan Masalah}

Berdasarkan latar belakang tersebut untuk mengetahui gambaran sebenarnya mengenai nilai perusahaan manufaktur makanan dan minuman yang terdapat di Bursa Efek Indonsia (BEI) maka masalah dalam penelitian ini adalah :

1. Bagaimana pengaruh likuiditas (current ratio) terhadap profitabilitas (return on asset) perusahaan manufaktur makanan dan minuman yang terdaftar di Bursa Efek Indonesia (BEI).

2. Bagaimana pengaruh Solvabilitas (bebt to equty ratio) terhadap profitabilitas (return on asset) perusahaan manufaktur makanan dan minuman yang terdaftar di Bursa Efek Indonesia (BEI).Untuk mengukur kemampuan perusahaan membayar kewajiban jangka pendek dengan aktiva lancar secara keseluruhan. Artinya jumlah kewajiban yang berumur dibawah satu tahun atau sama dengan satu tahun dibandingkan dengan total aktiva lancar.

\section{Kajian Pustaka}

Menurut Fahmi, (2012:121) jenis-jeni rasio likuiditas yang dapat digunakan terdiri dari:

1. Rasio Lancar (Current Ratio atau Rasio Lancar)

Merupkan rasio untuk mengukur kemampuan perusahaan membayar kewajiban jangka pendek atau utang yang segera jatuh tempo pada saat ditagih secara keseluruhan. Dengan kata lain, seberapa banyak aktiva lancar yang tersedia untuk menutupi kewajiban jangka pendek yang segera jatuh tempo. Rasio lancar dapat pula dikatakan sebagai bentuk untuk mengukur tingkat keamanan (margin of safety) suatu perusahaan. Rasio ini mengguakan rumus sebagai berikut:

$$
\text { Rasio Lancar }=\frac{\text { AktivaLancar }}{\text { HutangLancar }} \times 100 \%
$$

2. Rasio Cepat (Quick Ratio)

Rasio cepat (quick ratio) atau rasio sangat lancar acid rest ratio merupakan rasio yang menunjukkan kemampuan perusahaan memenuhi atau membayar kewajiban atau utang lancar (utang jangka pendek) dengan 


\section{Jurnal Buana Akuntansi}

aktiva lancar tanpa memperhitungkan nilai persediaan (inventory). Artinya, nilai persediaan kita abaikan, dengan cara dikurangi dari nilai total aktiva lancar.

Hal ini dilakukan karena persediaan dianggap memerlukan waktu relatif lebih lama untuk diuangkan, apabila perusahaan membutuhkan dana cepat untuk membayar kewajiban dibandingkan dengan aktiva lancar lainnya.

Rasio ini menggunakan rumus sebagai berikut:

$$
\text { Rasio Lancar }=\frac{\text { AktivaLancar-persdiaan }}{\text { HutangLancar }} \times 100 \%
$$

3. Rasio Kas atas Aktiva Lancar

Rasio ini menunjukan porsi jumlah kas dibandingkan dengan total aktiva lancar. Rasio ini dapat dihitung rumus sebagai berikut:

$$
\text { Rasio kas atas rasio lancar }=\frac{\text { kas }}{\text { AktivaLancar }} \times 100 \%
$$

4. Rasio Kas atas Utang Lancar

Rasio ini menunjukan porsi kas yang dapat menutupi hutang lancar. Rasio ini dapat dihitung dengan rumus sebagai berikut:

$$
\text { Rasio lancar }=\frac{\text { kas }}{\text { HutangLancar }} \times 100 \%
$$

\section{Solvabilitas}

Menurut Kasmir (2012:151), “Rasio Solvabilitas atau Leverage Ratio merupakan rasio yang digunakan untuk mengukur sejauh mana aktiva perusahaan dibiayai dengan utang. Artinya berapa besar beban utang yang ditanggung perusahaan dibandingkan dengan aktivanya".

\section{Jenis-jenis Rasio Solvabilitas}

1. Debt to Asset Ratio

Rasio yang bisa disebut dengan rasio hutang (debt ratio) ini mengukur presentase besarnya dana yang berasal dari hutang. Untuk mengukur besarnya rasio hutang ini digunakan rumus:

Debt Ratio $=\frac{\text { Total Hutang }}{\text { Total Aktiva }} \times 100 \%$

Rasio ini ditunjukkan sejauh mana hutang dapat ditutupi oleh aktiva.

Semakin kecil rasionya semakin aman (solvable).

2) Debt to Equity Ratio 


\section{Jurnal Buana Akuntansi}

Rasio hutang dengan modal sendiri (debt to equty ratio) adalah imbangan antara hutang yang dimiliki perusahaan dengan modal sendiri, Semakin kecil rasio ini semakin baik. Artinya, semakin kecil porsi hutang terhadap modal, semakin aman. Rumusnya:

$$
\text { Debt to Equity Ratio }=\frac{\text { Total Hutang }}{\text { Modal }} \times 100 \%
$$

3) Time Interest Earned Ratio

Time Interest Earned Ratio mengukur seberapa besar keuntungan dapat berkurang (turun) tanpa mengakibatkan adanya kesulitan keuangan karena perusahaan tidak mampu membayar bunga. Rasio yang tinggi menunjukkan situasi yang aman, meskipun barangkali juga menunjukkan terlalu rendahnya penggunaan hutang (penggunaan financial leverage) perusahaan. Rumusnya:

$$
\text { Time Interst Earned }=\frac{\text { Laba Sebelumnya dan Pajak }(\text { EBIT })}{\text { Beban Bunga }}
$$

4) Fixed Charge Coverage

Fixed Charge Coverage berfungsi untuk mengukur kemampuan perusahaan untuk membayar beban tetapnya berupa bunga dan sewa. Rumus :

Fixed Charge Coverage $=\frac{\text { Laba Sebelumnya dan Pajak }(\text { EBIT })+\text { Sewa }}{\text { Beban Bunga }+ \text { Pembayaran Sewa }}$

5) Cash Flow Coverage

Cash Flow Coverage digunakan untuk mengukur kemampuan perusahaan untuk memenuhi kewajiban kas . rumusnya :

Cash Flow Coverage $=$ Aliran Kas Masuk + Depresiasi

Beban Tetap $=\frac{\text { Deviden ShPreferen }}{(1-\text { Pajak })}+\frac{\text { Deviden ShPreferen }}{(1-\text { Pajak })}$

\section{Profitabilitas}

Menurut Mamduh M. Hanafi (2009:81), rasio profitabilitas adalah “rasio yang mengukur kemampuan perusahaan menghasilkan keuntungan (profitabilitas) pada tingkat penjualan, aset, dan modal saham yang tertentu".

\section{Jenis-Jenis Rasio Profitabilitas}

Terdapat beberapa jenis rasio profitabilitas yang dapat digunakan untuk mengukur kemampuan perusahaan.

Menurut Sutrisno (2012:222) jenis-jenis rasio profitabilitas yaitu: 
1. Net Profit Margin Mencerminkan kemampuan perusahaan dalam menghasilkan keuntungan dari setiap penjualan.

Net Profit Margin $=\frac{\text { Penjwalan Bersih }- \text { Harga Poko Penjualan (lababersih })}{\text { Penjwalan }}$

2. Return On Assets Sering disebut sebagai rentabilitas ekonomis merupakan ukuran kemampuan perusahaan dalam menghasilkan laba dengan semua aktiva yang dimiliki oleh perusahaan.

Return On Asset $=\frac{\text { LabaBersih }}{\text { TotalAktiva }}$

3. Return on Equity Kemampuan perusahaan dalam menghasilkan keuntungan dengan modal sendiri yang dimiliki.

Return On Equity $=\frac{\text { LabaBersih }}{\text { Modal }}$

Adapun jenis-jenis rasio profitabilitas menurut Sudana (2011:22) dalam Julita (2013) :

1. Return on Total Assets (ROA)

2. Return on Equity (ROE)

3. Profit Margin Ratio

\section{Kerangka Berpikir}

Sebagai gambaran dalam penyelesaian masalah maka diperlukan adanya kerangka teoritik yang terperinci, agar penelitian ini akan lebih terarah. Adapun kerangka teoritik tersebut dapat digambarkan sebagai berikut:

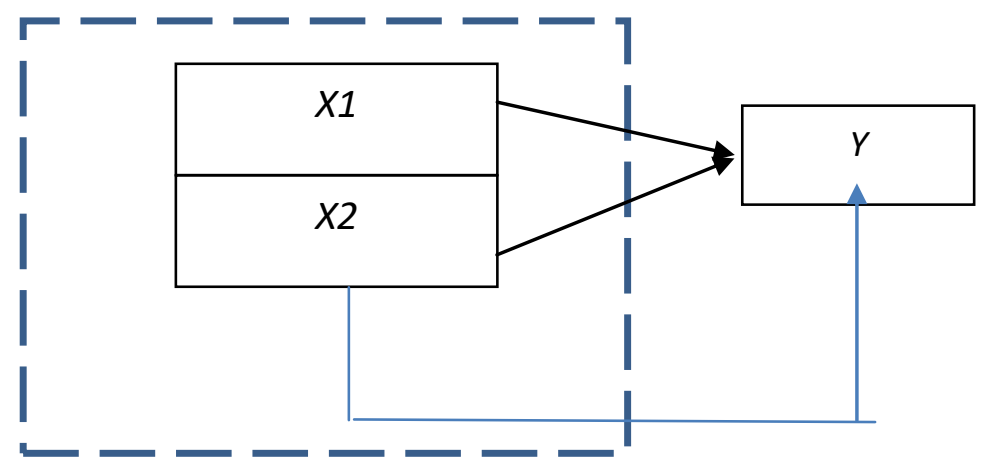

Keterangan:

1. $\mathrm{X} 1$ : Likuiditas

2. X2 :Solvabilitas 


\section{Jurnal Buana Akuntansi}

3. $\mathrm{Y}$ : Profitabilitas

\section{Hipotesis Penelitian}

Berdasarkan pada hasil tersebut, peneliti memprediksi bahwa current ratio (X1) dapat dijadikan sebagai pediktor return on asset $(\mathrm{Y})$. Maka, hipotesis pertama dari penelitian ini yaitu:

$\mathrm{H} 1$ : current ratio $(\mathrm{X} 1)$ berpengaruh terhadap return on asset $(\mathrm{Y})$

Berdasarkan pada hasil tersebut, peneliti memprediksi bahwa debt to equity ratio (X2) dapat dijadikan sebagai prediktor profitabilitas (return on asset) (Y). Maka, hipotesis kedua dari penelitian ini yaitu:

$\mathrm{H} 2$ : Debt to equity ratio (X2) berpengaruh terhadap return on asset (Y)

\section{Alat Analisis}

Data yang diperoleh dari perusahaan diolah serta di analisis dengan menggunakan metode statistik yaitu dengan menggunakan analisis regresi linear berganda dengan menggunakan SPSS untuk mengetahui hubungan dan pengaruh dari hutang terhadap profitabilitas perusahaan.

1. Analisis Deskriptif

2. Uji Asumsi Klasik
a. Uji Normalitas
b. Uji Multikolinearitas
c. Uji Heteroskedastisitas
d. Uji Autokorelasi

3. Uji Ketepatan Model
a. Uji F
b. Uji Determinasi

4. Pengujian Hipotesis

5. Analisis Regresi Linear Berganda

\section{Metodologi Riset}

Penelitian ini merupakan penelitian kuantitatif. Metode kuantitatif dinamakan metode tradisional, karena metode ini cukup lama digunakan sehingga sudah mentradisi sebagai metode untuk penelitian. Metode ini disebut sebagai metode positivistik karena berlandasksan pada filsafat positivisme

\section{Populasi dan Sampel}

\section{Populasi}

Dalam penelitian, kata populasi digunakan untuk menyebutkan serumpun atau kelompok objek yang menjadi sasaran penelitian.

Populasi dalam penelitian ini adalah perusahaan yang terdaftar di Bursa Efek Indonesia (BEI). 


\section{Jurnal Buana Akuntansi}

\section{Sampel}

Sampel adalah bagian dari jumlah dan karakteristik yang dimiliki oleh populasi tersebut (Sugiyono, 2016:115). Jadi sampel adalah bagian dari populasi (contoh), untuk dijadikan sebagai bahan penelaahan yang berharap contoh yang diambil dari populasi tersebut dapat mewakili populasinya. Sampel dalam penelitian ini adalah perusahaan Makanan dan Minuman yang terdaftar di Bursa Efek Indonesia (BEI) periode 2012-2016.

\section{Teknik Pengambilan Sampel}

Teknik pengambilan sampel dalam penelitian ini adalah purposiv sampling yakni penarikan sampel dengan pertimbangan tertentu.

1. Perusahaan makanan dan minuman yang terdaftar di Bursa Efek Indonesia (BEI) periode 2012 sampai dengan periode 2016.

2. Mengeluarkan laporan keuangan secara lengkap selama periode 2012 sampai 2016.

\section{Analisis Regresi Linear Berganda}

Secara umum analisis ini digunakan untuk menggambarkan hubungan linear dari beberapa variabel independen (variabel X) terhadap variabel dependen. Profitabilitas (variabel Y). Variabel independen dalam penelitian ini adalah current ratio $\left(\mathrm{X}_{1}\right)$, debt to equity ratio $\left(\mathrm{X}_{2}\right)$, sedangkan variabel independen (return on asset) $(\mathrm{Y})$ sehingga persamaan regresi bergandanya adalah :

$\mathrm{Y}=\mathrm{a}+\mathrm{b}_{1} \mathrm{X}_{1}+\mathrm{b}_{2} \mathrm{X}_{2}+\mathrm{e}$

Diminta :

\begin{tabular}{|c|c|}
\hline Y & $=$ Profitabilitas (return on asset) \\
\hline a & $=$ Konstanta \\
\hline b1,2 & $=$ Koefisien regresi \\
\hline $\mathrm{X}_{1}$ & $=\mathrm{CR}$ \\
\hline $\mathrm{X}_{2}$ & $=\mathrm{DER}$ \\
\hline & $=$ Standar error atau variable penggangu \\
\hline
\end{tabular}

Pada penelitian ini yang dijadikan objek penelitian adalah seluruh perusahaan makanan dan minuman yang terdaftar di Bursa Efek Indonesia (BEI) dari tahun 2012-2016. Teknik pengambilan sampel dalam penelitian ini adalah purposive sampling yakni penarikan sample dengan pertimbangan tertentu.

\begin{tabular}{|l|c|}
\hline \multicolumn{1}{|c|}{ Kriteria } & Jumlah \\
\hline $\begin{array}{l}\text { Perusahan Makanan dan Minuman yang terdaftar di Bursa } \\
\text { Efek Indonesia (BEI) }\end{array}$ & 14 \\
\hline $\begin{array}{l}\text { Perusahaan Makanan dan Minuman yang terdaftar di Bursa } \\
\text { Efek Indonesia (BEI) periode 2012-2016 }\end{array}$ & 9 \\
\hline $\begin{array}{l}\text { Mengeluarkan laporan keuangan tahunan secara lengkap } \\
\text { periode 2012-2016 }\end{array}$ & 9 \\
\hline Jumlah tahun penelitian & $\mathbf{4 5}$ \\
\hline Total Sampel & 5 \\
\hline
\end{tabular}

Sumber : Data yang diolah, 2019 


\section{Jurnal Buana Akuntansi}

Jumlah perusahaan makanan dan minuman yang terdaftar di Bursa Efek Indonesia (BEI) terdapat 14 perusahaan. Dari perusahaan tersebut terdapat 9 perusahaan makanan minuman yang konsisten terdapat di Bursa Efek Indonesia (BEI) periode 2012-2016. Dari 9 perusahaan tersebut semuanya konsisten melampirkan laporan keuangan tahunannya dari 2012-2016. Kemudian 9 perusahaan tersebut dikalikan 5 tahun penelitian sehingga 45 sempel dalam penelitian ini.

\section{Uji Ketepatan Model}

\section{Uji F}

Uji ketepatan model menggunakan uji F.

a. Menentukan Ho dan Ha

berarti model tidak tepat atau tidak layak untuk memprediksi pengaruh likuiditas dan solvabilitas terhadap viabel profitabilitas.

berarti model tepat atau layak untuk memprediksi pengaruh likuiditas dan solvabilitas terhadap viabel profitabilitas.

b. Level of significance $(a)=0,05$

Menentukkan level of significance, yaitu a $=0,05$ atau 5\%

c. Menentukan kriteria pengujian yaitu

Ho ditolak bila $p$ value $\geq 0,05$

Ho ditolak bila $p$ value $\leq 0,05$

\begin{tabular}{|c|r|r|r|r|r|}
\hline & ANOVA $^{\mathrm{a}}$ \\
\hline & Sum of Squares & Df & Mean Square & F & Sig. \\
\hline Regression &, 615 & 2 &, 307 & 6,095 &, $005^{\mathrm{b}}$ \\
Residual & 2,119 & 42 &, 050 & & \\
& 2,734 & 44 & & & \\
\hline
\end{tabular}

Hasil uji F diperoleh F hitung 6,095 dengan sig 0,005 < 0,05. Dengan demikian model tepat atau layak untuk diprediksi pengaruh variabel likuiditas dan solvabilitas terhadap variabel terikat (Return On Asset) pada perusahaan makanan dan minuman yang terdaftar di Bursa Efek Indonesia (BEI) tahun 20122016.

\section{Pengujian Hipotesis}

Kriteria pengujian yang digunakan dengan membandingkan nilai signifikan yang diperoleh dengan taraf signifikan yang telah ditentukan yaitu 0,05. Apabila nilai signifikan $<0,05$ maka variabel independen mampu mempengaruhi variabel dependen secara signifikan atau hipotesis diterima.

Berikut ini merupakan uji hipotesa untuk masing-masing variabel: 


\section{Uji Parsial}

\begin{tabular}{|c|c|c|c|c|c|}
\hline & \multicolumn{2}{|c|}{$\begin{array}{l}\text { Instandardized } \\
\text { Coefficients }\end{array}$} & \multirow{2}{*}{\begin{tabular}{|l|} 
dardized \\
fficients \\
Beta \\
\end{tabular}} & & \multirow[b]{2}{*}{ g. } \\
\hline & $\mathrm{B}$ & Error & & & \\
\hline ant) & ,907 & 187 & & 4,850 & , 000 \\
\hline itas (CR) & ,411 & 118 & 669 & 3,474 & ,001 \\
\hline ilitas (DER) & 143 & ,064 & , 428 & 2,219 & ,032 \\
\hline
\end{tabular}

Sumber: data diolah dengan spss 23 ( 2019)

Berdasarkan tabel Uji Parsial dapat disimpulkan sebagai berikut:

1. Pengaruh current ratio (CR) terhadap retun on asset (ROA)

Berdasarkan tabel 4.9 diperoleh Variabel Likuiditas (CR) memiliki nilai sig $(0,001)$ lebih rendah dari 0,05 maka Ha diterima artinya terdapat pengaruh signifikan dari Likuiditas (CR) terhadap Profitabilitas (ROA) pada perusahaan makanan dan minuman yang terdaftar di Bursa Efek Indonesia (BEI) tahun 20122016.

2. Pengaruh debt to equity ratio (DER) terhadap return on asset (ROA)

Berdasarkan tabel 4.9 diperoleh Variabel Solvabilitas (DER) memiliki nilai sig $(0,032)$ lebih rendah dari 0,05 maka Ha diterima artinya terdapat pengaruh signifikan dari Solvabilitas (DER) terhadap Profitabilitas (ROA) pada perusahaan makanan dan minuman yang terdaftar di Bursa Efek Indonesia (BEI) tahun 20120-2016.

\section{Analisis Regresi Linear Berganda}

Untuk melihat pengaruh Likuiditas (CR) dan Solvabilitas (DER) terhadap

Profitabilitas (ROA). Digunakan analisis regresi linier berganda dengan persamaan sebagai berikut:

$\mathrm{Y}=\mathrm{a}+\mathrm{b}_{1} \mathrm{X}_{1}+\mathrm{b}_{2} \mathrm{X}_{2}+\mathrm{e}$

Diminta :

$\begin{array}{ll}\mathrm{Y} & =\text { Profitabilitas (return on asset) } \\ \mathrm{a} & =\text { Konstanta } \\ \mathrm{b} 1,2 & =\text { Koefisien regresi } \\ \mathrm{X}_{1} & =\mathrm{CR} \\ \mathrm{X}_{2} & =\mathrm{DER} \\ \mathrm{e} & =\text { Standar error atau variable penggangu. }\end{array}$


Regresi Berganda

\begin{tabular}{|c|c|c|c|c|c|}
\hline & \multicolumn{2}{|c|}{$\begin{array}{r}\text { Unstandardized } \\
\text { Coefficients }\end{array}$} & \multirow{2}{*}{$\begin{array}{r}\begin{array}{r}\text { Standardized } \\
\text { Coefficients }\end{array} \\
\text { Beta }\end{array}$} & \multirow[b]{2}{*}{$\mathrm{t}$} & \multirow[b]{2}{*}{ Sig. } \\
\hline & $\mathrm{B}$ & Std. Error & & & \\
\hline (Constant) & ,907 & 187 & & 4,850 & 000 \\
\hline Likuiditas (CR) & ,411 & 118 & 669 & 3,474 & 001 \\
\hline Solvabilitas (DER) & 143 & ,064 & ,428 & 2,219 & ,032 \\
\hline
\end{tabular}

Berdasarkan hasil perhitungan pada tabel 4.10 diperoleh bentuk persamaan regresi linier berganda sebagai berikut:

$$
\mathrm{Y}=0,907+0,411 \mathrm{X} 1+0,143 \mathrm{X} 2
$$

Dari persamaan regresi linier berganda diatas diperoleh nilai konstanta sebesar 0,907. Artinya, jika variabel Profitabilitas (ROA) tidak dipengaruhi oleh kedua variabel independennya yaitu Likuiditas (CR) dan Solvabilitas (DER) bernilai nol, maka besarnya rata-rata Profitabilitas (ROA) akan bernilai 0,907.

Koefisien regresi untuk variabel Likuiditas (CR) bernilai positif, menunjukkan adanya hubungan yang searah antara Likuiditas (CR) dengan Profitabilitas (ROA). Koefisien regresi variabel Likuiditas (CR) sebesar 0,411 mengandung arti untuk setiap pertambahan Likuiditas (CR) sebesar satu satuan akan menyebabkan meningkatnya Profitabilitas (ROA) sebesar 0,411.

Koefisien regresi untuk variabel independen Solvabilitas (DER) bernilai positif, menunjukkan adanya hubungan yang searah antara Solvabilitas (DER) dengan Profitabilitas (ROA). Koefisien regresi variabel Solvabilitas (DER) sebesar 0,143 mengandung arti untuk setiap pertambahan Solvabilitas (DER) sebesar satu satuan akan menyebabkan meningkatnya Profitabilitas (ROA) sebesar 0,143.

\section{Pembahasan Hasil Penelitian}

\section{Pengaruh Likuiditas (Current Ratio) Terhadap Profitabilitas (Return On Asset)}

Berdasarkan analisis data dan pengujian hipotesis secara persial $(t)$ yang dilakukan dalam penelitian ini dari hasil perhitungannya diperoleh nilai signifikasi untuk current ratio dengan return on asset adalah $0,001<0,05$. Dengan demikian hipotesis Ha diterima, maka dapat diketahui bahwa current ratio (CR) berpengaruh terhadap return on asset (ROA). Kenaikan current ratio akan diikuti oleh kenaikan profitabilitas perusahaan. Penelitian ini mempunyai kesamaan hasil dengan penelitian yang dilakukan oleh Yudistira (2012), dimana current ratio (CR) berpengaruh terhadap profitabilitas pada Perusahaan Manufaktur yang Terdaftar di BEI.Hal ini berarti semakin besar nilai current ratio maka diindikasikan profitabilitasnya akan semakin meningkat.

\section{Pengaruh Solvabilitas (Debt to Equity Ratio) Terhadap Profitabilitas(Return On Asset)}

Berdasarkan analisis data dan pengujian hipotesis secara persial ( $\mathrm{t}$ ) yang dilakukan dalam penelitian ini dari hasil perhitungannya diperoleh nilai 


\section{Jurnal Buana Akuntansi}

signifikasi untuk debt to equity ratio dengan return on asset adalah $0,032<$ 0,05.Dengan demikian hipotesis Ha diterima, maka dapat diketahui bahwa debt to equity ratio (DER) berpengaruh terhadap return on asset (ROA). Kenaikan debt to equity ratio akan diikuti oleh kenaikan profitabilitas perusahaan.Hasil ini menunjukkan bahwa semakin meningkat debt to equity ratio maka diikuti dengan kenaikan Profitabilitasnya. Perusahaan yang memiliki Solvabilitas yang tinggi, maka akan mempunyai resiko kerugian besar, tetapi juga mempunyai kesempatan memperoleh laba yang besar pula dari pera penanam modal.

\section{Kesimpulan}

Berdasarkan penelitian yang dilakukan pada perusahaan makanan dan minuman yang terdaftar di Bursa Efek Indonesia (BEI) tahun 2012-2016 dalam memprediksi return on asset diperoleh hasil dan dapat dibuat kesimpulan sebagai berikut :

1. Hipotesis 1 diterima, artinya current ratio berpengaruh terhadap return on asset pada perusahaan makanan dan minuman yang terdaftar di Bursa Efek Indonesia (BEI) tahun 2012-2016. Berdasarkan perhitungan diperoleh nilai signifikasi untuk current ratio dengan return on asset $0,001<0,05$.

2. Hipotesis 2 diterima, artinya deb to equity ratio berpengaruh terhadap return on asset pada perusahaan makanan dan minman yang terdaftar di Bursa Efek Indonesia (BEI) tahun 2012-2016. Berdasarkan perhitungan diperoleh nilai signifikansi untuk debt to equity ratio dengan return on asset $0,032<0,05$.

\section{Saran}

Saran-saran yang dapat diberikan sebagai tindak lanjut dari hasil penelitian adalah sebagai berikut :

1. Bagi perusahaan diharapkan meningkatkan kualitas aktiva produktif yang dimilikinya serta berupaya berhati-hati dalam mengelolanya, karena telah terbukti bahwa cuuret ratio (CR) berpengaruh terhadap return on asset (ROA).

2. Bagi perusahaan diharapkan meningkatkan kualitas aktiva produktif yang dimilikinya serta berupaya berhati-hati dalam mengelolanya, karena telah terbukti bahwa debt to equity ratio (DER)berpengaruh terhadap return on asset (ROA).

3. Untuk perusahaan yang menjadi objek dalam penelitian ini, pihak manajemen harus lebih mempertimbangkan penggunaan utang sebagai sumber dana perusahaan, serta lebih optimal dalam mengelolanya, hal ini karena telah terbukti likuiditas dan solvabilitas dapat berpengaruh signifikan terhadap profitabilitas, walaupun masih ada berbagai kemungkinan atau faktor lain yang terjadi.

4. Untuk melihat konsistensi hasil penelitian dari tahun ke tahun dan lebih kuatnya kebenaran hasil penelitian ini, sebaiknya penelitian yang akan datang dapat menambah subjek penelitian, dan metode penelitian sebagai alat pengukurannya variabel lain, menambah sempel yang akan diteliti, dapat juga memperluas periode penelitian yang akan diteliti. 


\section{Jurnal Buana Akuntansi}

\section{DAFTAR PUSTAKA}

Asri Nur Wahyuni dan Surya Kusuma K.H (2018). Analisis Likuiditas, Solvabilitas, dan Aktivitas Perusahaan Terhadap Profitabilitas Pada Perusahaan Manufaktur". JurnalManajemen, (volume 15 no 1).

Erica, Deni. (2016). Analisis Rasio Keuangan untuk Menilai Kinerja Perusahaan. Studi Empiris PT Kino Indonesia. Jurnal Ecodemica, (volume 2 no 1)

Febriyanti, R. (2012). "Pengaruh Perputaran Modal Kerja dan Rasio Hutang Terhadap Profitabilitas pada PT. Jasa asuransi indonesia (Persero)", dalam skripsi Universitas Komputer Indonesia (UNIKOM) Bandung.

Ghozali, Imam. (2016). AplikasiAnalisisMutivariatedengan Program IBM SPSS 23. Semarang: BPFE Universitas Diponogoro.

Halil, Muhammad. (2014). Pengaruh Rasio Leverage dan Aktivitas Profitabilitas Pada Peusahaan Ritel yang Terdaftar di Bursa Efek Indonesia (BEI) Periode 2009-2012. Jurnal. Universitas Maritim Raja Ali Haji.

Hartono. (2015). Pengaruh Current Ratio dan Debt To Equity Ratio Terhadap Profitabilitas Pada Perusahaan Manufaktur Sektor Logam dan Sejenisnya yang Terdaftar di Bursa Efek Indonesia Periode 2009-2013. Jurnal Wika Ekonomi Mikroskil. Volume 5 Nomer 1, April 2015. Universitas Prima Indonesia.

Hastuti, N. (2010). Analisis Pengaruh Periode Perputaran Persediaan, Periode Perputaran Hutang Dagang, Rasio Lancar, Leverege, Pertumbuhan Penjualan, dan Ukuran Perusahaan Terhadap Profitabilitas Perusahaan pada Perusahaan Manufaktur yang Terdaftar di BEI periode 2006-2008. Skripsi. Universitas diponogor Semarang.

Irawan, N. (2012). "Pengaruh Rasio Likuiditas Terhadap Rasio Profitabilitas pada Bank Syari'ah di Indonesia (Studi Kasus Tahun 2007-2009)", dalam Skripsi Universitas Islam Negeri (UIN) Walisongo Semarang.

Jannati, I.D., M. Saifi dan M.G.W.I.Endang. (2014). Pengaruh Rasio Leverege Terhadap Profitabilitas (Studi Pada Perusahaan Makanan dan Minuman. yang Terdaftar di BEI Periode 2009-2011). Jurnal Administrasi Bisnis. Vol. 8 No. 2.

Prof. Dr. Sugiyono. (2016). Metode Penelitian. Bandung. Alfabeta.

Raymond (2017). Pengaruh Likuiditas dan Solvabilitas Terhadap Profitabilitas pada PT Indosat Tbk. jurnal Manajemen Universitas Putera Batam.

Ribud Wahidi Prakoso. (2017). "Pengaruh Likuiditas dan Solvabilitas Terhadap Profitabilitas Studi Pada Perusahaan Makanan dan Minuman yang Terdaftar di Indeks Saham Syari'ah Indonesia (ISSI) Periode 2012-2-16. Dalam skripsi Institut Agama Islam Negeri Sukakarta.

Standar Akuntansi Keuangan. (2015). Analisis Laporan Keuangan. Pustaka Baru Press.

V. Wiratna Sujarweni. (2017). Analisis Laporan Keuangan. Pustaka Baru Press. 